\title{
FEM Analysis of Stress in Non-carious Cervical Lesion Restoration with Four Different Restorative Materials
}

\author{
GABRIELA BERESESCU1, ALINA ORMENISAN ${ }^{1 *}$, RALUCA MONICA COMANEANU2, ANDREEA MARILENA CARP VELISCU³, \\ MARINELA MINODORA MANEA ${ }^{4,5}$, RAZVAN ION ${ }^{6}$ \\ ${ }^{1}$ University of Medicine and Pharmacy Tirgu Mures, Faculty of Dental Medicine, 38 Ghe. Marinescu Str, 540139, Tirgu Mures, \\ Romania \\ ${ }^{2}$ Titu Maiorescu University of Bucharest, Faculty of Dental Medicine, 67A Gheorghe Petrascu Str., 031593, Bucharest, Romania \\ 3University of Medicine and Pharmacy Carol Davila, Faculty of Medicine, 8 Eroii Sanitari Blvd, 050474, Bucharest, Romania \\ 4University of Medicine and Pharmacy luliu Hatieganu, Department of Medical Psychology, 8 Victor Babes Str, 400012, Cluj \\ Napoca, Romania \\ ${ }^{5}$ County Emergency Clinical Hospital Cluj Napoca, Psychiatric Clinic 3, 3-5 Clinicilor Str., 400000, Cluj Napoca, Romania \\ 6University of Medicine and Pharmacy Tirgu Mures, Faculty of Medicine, 38 Ghe. Marinescu Str, 540139, Tirgu Mures, \\ Romania
}

\begin{abstract}
The purpose of this study was to evaluate the behavior of four restorative materials in non-carious cervical lesions when subjected to exterior stresses of different magnitude. A plane model reproducing a vestibular and lingual section of the lower canine was created. The finite elements are of a two-dimensional type (2D) - quadrilater. Four restorative materials were used: Vitrebond, DyractAP, Vitremer, Fuji IX. All materials were considered to be isotropic and elastic. Nodal charges were of 40 degrees to vertical, applied on the vestibular side at $h=8.993 \mathrm{~mm}$ to gingival crest, of increasing magnitudes:20, 40,60,80,100,120, 140, $160 \mathrm{~N}$. The results of this study showed that after restoration stress values in all the elements are (with minimal differences) similar to those in the healthy tooth; a correct restoration leads to normal functioning of the tooth. It can be considered that particular types of restoring materials should be used in particular lesions to be restored, depending on the location of the lesion and the elastic characteristics of the materials and tooth structure. A correct restoration leads to normal functioning of the tooth.
\end{abstract}

Keywords: Finite Element Analysis, cervical lesion, stress, restorative materials

Human tooth represents a natural wonder. However, there is a major deficiency, namely, its limited capacity for regeneration. Thus, the necessity of replacing the lost structure resulting from cervical lesions, traumas, or other causes, by means of restorative materials.

Cervical lesion restoration represents a unique clinical situation due to their unclear etiology. Noncarious cervical lesions (NCCL) are considerable restorative challenges for the dentist [1]. NCCL are defined as the loss of tooth structure at the cement-enamel junction. However, literature also describes other destructive processes that originate on the external surface of the tooth and affect it causing irreversible damage to the tooth structure, such as erosion, abrasion, attrition and abfraction [2, 3]. The etiologies of NCCLs are multifactorial, and therefore difficult to categorize into being caused by only abrasion, erosion, or abfraction [3].

The tooth has not a rigid structure, hence it can suffer strains when various forces/loads are applied. Intraoral loads vary from $10 \mathrm{~N}$ to $430 \mathrm{~N}$, the normal clinical values being considered of $70 \mathrm{~N}$ [4]. One current hypothesis is that the tensile or compressive strains gradually produce micro fractures.

FEM consist of building a continuous material from smaller elements called finite elements, which interconnect in a finite number of points called nodes. FEM allows stress analysis of a given structure. Studies showed that mechanical overloading of cervical enamel can induce NCCL [5]. Recently, clinicians have been performing minimal preparations along with NCCL treatment.

Restoration failure can occur as a result of strain applied on the tooth, fallowing occlusal contacts [6]. Other authors confirmed cervical cavities strain under occlusal stress suggesting biomechanical actions of the tooth as possible factors of restoration failure $[7,8]$.

\footnotetext{
* email: ormenisanalina@yahoo.fr; Phone. 0741248373
}

The purpose of this study was to evaluate the behavior of four restorative materials in non-carious cervical lesions restored without preparation.

\section{Experimental part}

A 2D mathematical finite elements analysis model was generated. A plane model reproducing a vestibular and lingual section of the lower canine was created. The quality of the analysis results depends on the accuracy of the model 9 [9].

Four restorative materials were used: Vitrebond (conventional glass ionomer cement, CGIC1), Dyract AP (polyacid-modified resin composite, PAMRC), Vitremer (resin-modified glass-ionomer cement, RMGIC), Fuji IX (glass-ionomer cement with high viscosity, CGIC2). All materials were considered to be isotropic and elastic.

Longitudinal elastic modulus (Young's modulus E) and Poisson's ratio $m$ values for the materials used in the model were derived from standard texts $[3,10,11]$.

In order to obtain a situation as close to reality as possible, the model loading was achieved with a charge distributed on five different nodes. Nodal charges were of 40 degrees to vertical, applied on the vestibular side at $h=8.993 \mathrm{~mm}$ to colet, of increasing magnitudes: 20, 40,60, 80, 100, 120, $140,160 \mathrm{~N}$.

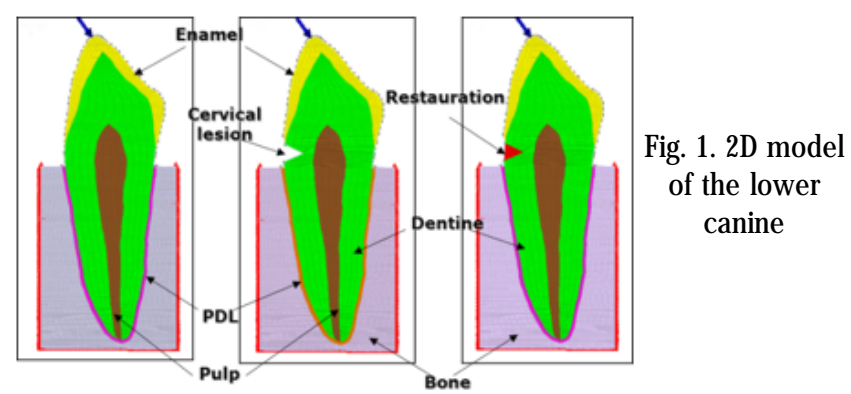


Table 1

PROPERTIES OF DENTAL TISSUE AND DENTAL MATERIALS

\begin{tabular}{|l|l|l|}
\hline Materials & $\begin{array}{l}\text { Young's modulus } \\
E[\mathrm{MPa}]\end{array}$ & $\begin{array}{l}\text { Poisson's } \\
\text { ratio } \mu\end{array}$ \\
\hline Enamel & $6.910^{4}$ & 0.30 \\
\hline Dentine & $1.6710^{4}$ & 0,31 \\
\hline PDL & 12 & 0.45 \\
\hline Bone & $1.4710^{4}$ & 0.3 \\
\hline Pulp & 2 & 0.45 \\
\hline CGIC 1 & $1.0810^{4}$ & 0.3 \\
\hline PAMRC & $1.0710^{4}$ & 0.28 \\
\hline RMGIC & $0.9810^{4}$ & 0.3 \\
\hline CGIC 2 & $1.7210^{4}$ & 0.3 \\
\hline
\end{tabular}

To compare the Young's modulus of the dentine, in which the lesion is found, to those of the restoration materials, the stress $\sigma[\mathrm{MPa}]$ was plotted against strain $\varepsilon[\mathrm{mm} / \mathrm{mm}]$.

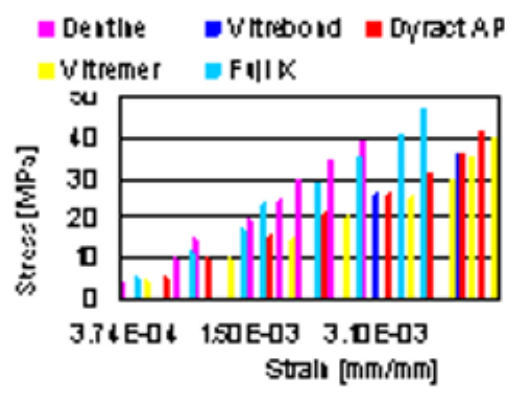

Fig. 2. Stress [MPa] Strain $[\mathrm{mm} / \mathrm{mm}]$ Dentine-VitrebondDyractAP-Vitremer-Fuji IX

\section{Results and discussions}

The significant results bearing relevance to the phenomena are the following: von Mises stress, Minimum Principal Stresses and displacements of the structure.

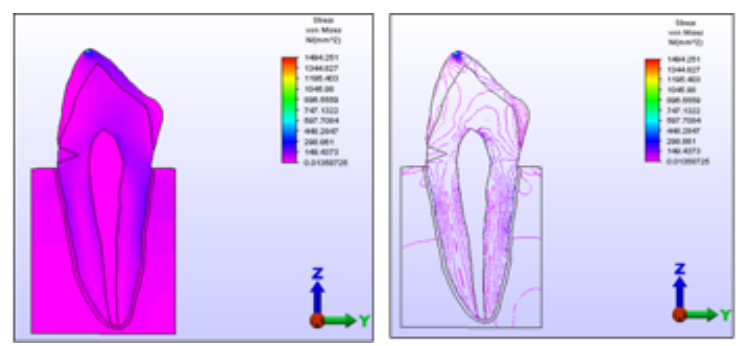

Fig. 3. Restauration with Vitrebond. Von Mises stresses for $F=160 \mathrm{~N}$
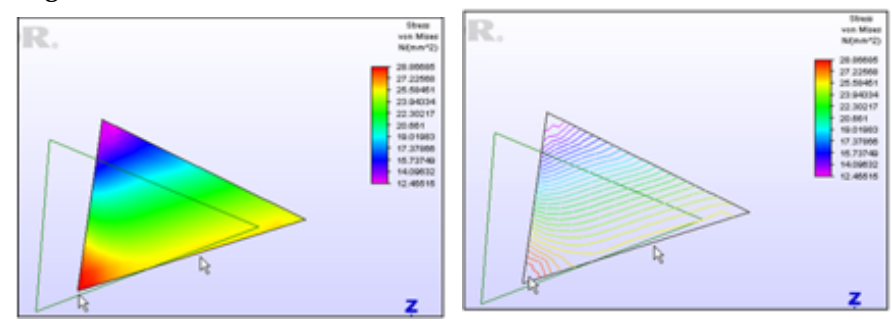

Fig 4. Details. Vitrebond restauration - Stress Von Mises for $F=160 \mathrm{~N}$
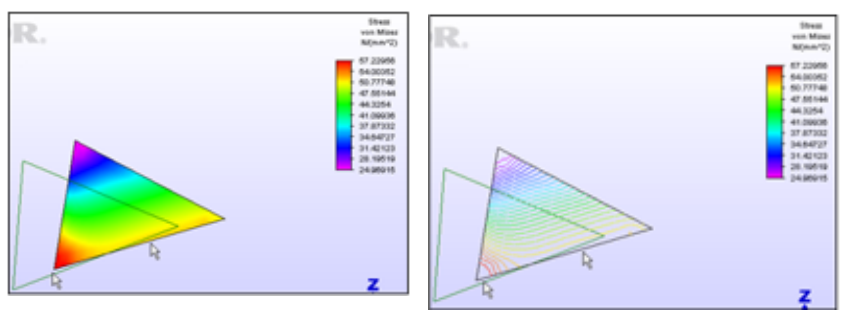

Fig 5. Details. Dyract AP restauration - Stress Von Mises for $F=160 \mathrm{~N}$
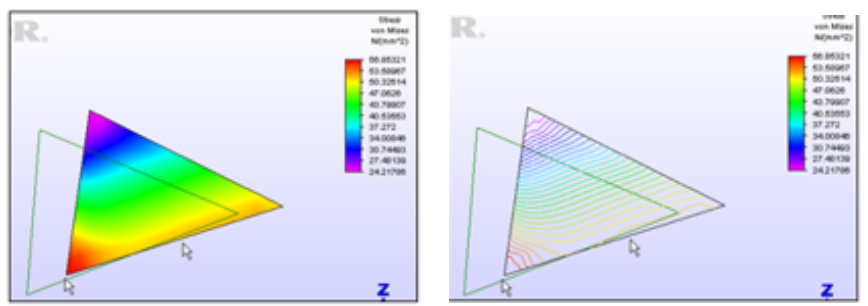

Fig 6. Details. Vitremer restauration - Stress Von Mises for $F=160 \mathrm{~N}$
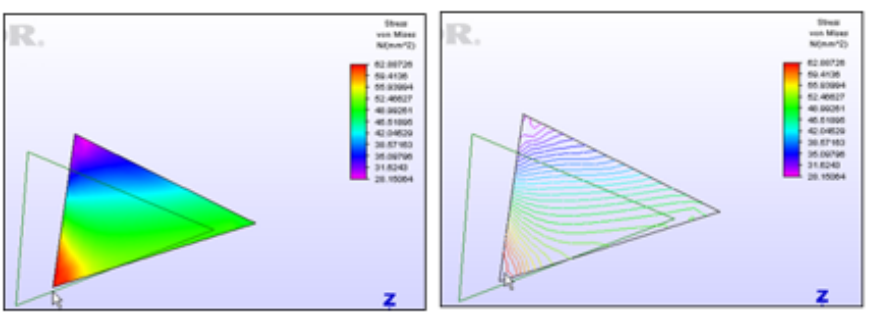

Fig 7. Details. Fuji IX restauration - Stress Von Mises for $F=160 \mathrm{~N}$

Based on the results of this study it can be assessed that:

- After restoration stress values in all the elements are (with minimal differences) similar to those in the healthy tooth; a correct restoration leads to normal functioning of the tooth;

- When restoring a lesion, maximum strain is directed onto the apex of the restoration irrespective of material and stress magnitude;

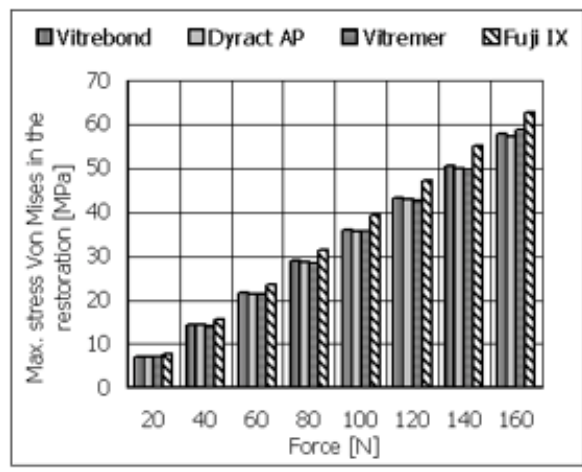

Fig. 8 Von Mises Stress in the restoration:

Vitrebond -Dyract AP-Vitremer -Fuji IX

- Restorations will be damaged by loads exceeding their strength capacity.

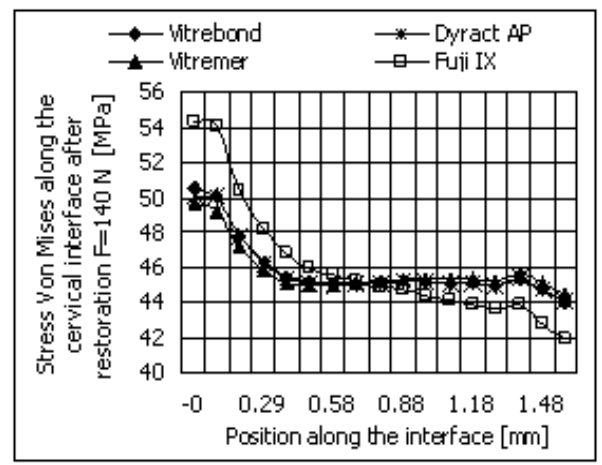

Fig. 9. Von Mises Stress distribution along the cervical interface of the restoration 
Loads of values exceeding $F=80 \mathrm{~N}$ will damage the tooth structure considering that dentine strength is $\sim \sigma_{\text {a dentine }}=105.5 \mathrm{MPa}$;

Stress values in dentine tend to equalize, presenting lower values for Fuji IX, compared with Vitrebond, Dyract AP or Vitremer; it can be concluded that Fuji IX, with its elastic characteristics close to those of dentine, undergoes a stress pattern similar to that of the healthy tooth.

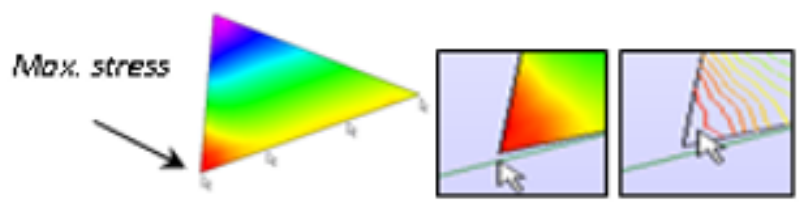

Fig 10. Von Mises Stress along the cervical interface

Our study is based on the golden rule in engineering according to which any stress will always follow the direction of the most rigid material $[10,12]$, that is to say, of the material with the highest elastic modulus.

The results obtained showed that:

a. in the healthy tooth

-maximum stress occurs in the cervical area irrespective of load direction;

-maximum stress values occur at $0.1 \mathrm{~mm}$ above the cervical line;

- stress values in the cervical area increase with occlusal loads values;

-Von Mises equivalent stress values for the same value of the load are higher for oblique loads.

The results show that from a mechanic stand point, the maximum strain appears in the cervical area at $0.1 \mathrm{~mm}$ above the cervical line, irrespective of load direction. This is the area were the tooth is most exposed to flexure leading to a concentration of stress which increases with the occlusal forces, ultimately leading to cracks.

$b$. in the restored tooth

-after reconstruction, stress values in all structure elements register differences similar to those in the healthy tooth;

-stress values in the dentine exhibit very close figures, indicating that the reconstruction material undergoes the same distribution of stress as the healthy tooth;

-maximum strain in the reconstruction appears in the bottom of it irrespective of the material used, direction and magnitude of loads;

- considering that maximum strength for dentine $\sim \sigma$ a deptine $=105.5 \mathrm{MPa}$ [5], it became clear that loads higher then $\mathrm{F}=80 \mathrm{~N}$ will damage the tooth structure.

Marcauteanu et all showed in their study that the class v restorations with compomer can have an unpredictable prognosis without a previous occlusal equilibration [13]. After the study of Mahmoud et al, adhesive remnant index quantity of dental composites is inversely proportional with their shear bond strength [14]. When choosing a particular restorative material, it is quite important to consider the needs of the individual patient $[15,16]$. As noted by McComb et. al., xerostomic patients can benefit significantly from additional fluoride. However, the type of lesion may also play a role in selection of restorative material [17]. After the severity of the dentin sensitivity, the clinical management of abfraction by in-office therapies with the recent introduced materials and technologies $[18,19]$. Terry et al. indicates that non-carious abfraction lesions may be caused by deflective occlusal contacts. Stress and flexing may cause loss of tooth structure in the cervical area. In this situation, we can recall the tooth flexure theory, in which composites with a low modulus of elasticity (e.g., microfill and flowable) may be the optimal restorative material [20]. In addition, situations requiring optimal esthetics (all other factors excluded) can generally be best restored with composite resin based on the general properties of this material. Fine filler sizes, shape, orientation, and concentration create better polishing characteristics in the small-particle hybrid and microhybrid composites [21].

\section{Conclusions}

It can be considered that particular types of restoring materials should be used in particular lesions to be restored, depending on the location of the lesion and the elastic characteristics of the materials and tooth structure (dentine or enamel):

Lesions in areas of elastic material, such as dentine in the colet, will require Fuji IX, followed by Vitrebond, Dyract AP and Vitremer;

Lesions in areas of higher rigidity such enamel will require Fuji IX.

von Mises values developed in all the elements of the healthy dental structure exhibited lesser figures than the same values in the cervical lesioned tooth, in all models.

The maximum strain occurs in the bottom of the lesion which constitutes a stress concentrator

Stress distribution on restored tooth apex presents the same values, irrespective of situation, i.e. exhibiting maximum value at tooth/restoration level, on the external surface. A correct restoration leads to normal functioning of the tooth.

\section{References}

1. ICHIM, I, LI, Q, LOUGHRAN, J, SWAIN, MV, KIESER, J, Restoration of non-carious cervical lesions. Part I. Modelling of restorative fracture, Dental Materials J ournal, 23, 2007, p.1553-1561.

2. HILDEBRANDT, G., HILL, G., PHAIR, C., Operative Dentistry I. 5801 $\& 5802$ Course Manual. University of Minnesota School of Dentistry, Minneapolis, 44, 2003, p.126-226.

3. PICCIONI, M.A.R.V., CAMPOS, E.A., SAAD, JRC, DE ANDRADE, M.F., GALVAO, M.R., RACHED, A.A., Application of the finite element method in dentistry, RSBO,2013 Oct-Dec,10(4), p. 369-377.

4. LUSSI, A., SCHAFFNER, M., Progression of and risk factors for dental erosion and wedge shaped defects over a 6 -year period. Caries Res. 2000 Mar-Apr; 34, 2, p.182-187.

5. GURBUZ, T., SENGUL, F., ALTUN, C., Finite Element Stress Analysis of Short-post Core and Over Restorations Prepared with Different Restorative Materials, Dental Materials J ournal, 27, 4, 2008, p. 499-507. 6. REES, J.S., HAMMADEH, M., J AGGER, D.C., Abfraction lesion formation in maxillary incisors, canines and premolars: a finite element study. Eur J Oral Sci., 111, 2, 2003, p.149-154.

7. DEJAK, B., MLOTKOWSKI, A., ROMANOWICZ, M., Finite element analysis of mechanism of cervical lesion formation in simulated molars during mastication and parafunction, The Journal of Prosthetic Dentistry, 94, No 6, 2005, p.520-529.

8. BOITOR, C., FRATILA, A., IONAS, M., PASCU, A., OLEKSIK, V., PARVU, B., Analiza prin metoda elementului finit a leziunilor de abfractie dentara, Revista Romana de Stomatologie, Vol LV, Nr. 4, 2009, p. 263267.

9. NARAYANASWAMY, S, MEENA, N, SHETTY, A, KUMARI, A, NAVEEN, DN, Finite element analysis of stress concentration in Class $V$ restorations of four groups of restorative materials in mandibular premolar, Journal of Conservative Dentistry,113, 2008, p. 121-128.

10. PALAMARA J E.A., PALAMARA D., MESSER H.H., TYAS M.J., Tooth morphology and characteristics of non-carious cervical lesion, J ournal of Dentistry, 34, 2006, p. 185-194.

11. REES S., HAMMADEH M., Undermining of enamel as a mechanism of abfraction lesion formation: a finite element study, European J ournal of Oral Sciences, 112, 2004, p. 347-352.

12. ROBERSON TM, HEYMANN HO, SWIFT EJ, Art and Science of Operative Dentistry, Mosby, 2006. 
13. MARCAUTEANU, C, NEGRUTIU, M.L., ARDELEAN, L, RUSU, L.C., PODOLEANU, A., Rev Chim (Bucharest), 63, no 5, 2012, p.545.

14. MAHMOUD, E., PACURAR, M., BECHIR, E.S., MARIS, M., OLTEANU, C., DASCALU, I.T., MOLDOVAN, M., Comparison of Shear Bond Strength and Adhesive Remnant Index of Brackets Bonded with Two Types of Orthodontic Adhesives, Mat. Plast., 54, no. 1, 2017, p. 141

15. COMAN, C., GHERGHIC, D.L., PATROI, D.N., TARCOLEA, M., COMANEANU, R.M., BARBU, H.M., Comparative Assessment of Resistance Against Experimental Forces of Mixed Prosthetic Restorations, Mat. Plast., 53, no. 1, 2016, p. 91

16. MCCOMB, D.,ERICKSON, R.L.,MAXYMIW, W.G.,WOOD, R.E., A clinical comparison of glassionomer, resin-modified glass ionomer and resin composite restorations in the treatment of cervical caries in xerostomic head and neck radiation patients.Operative Dentistry, 27, 5, 2002 Sep-Oct, p. 430-437.

17. FLORESCU, A., PANGICA A.M., HANCU, V., MANU, R., BICLESANU, C.F., FEM study regarding materials retention used for abfraction adhesive restoration, Mat. Plast., 53, no. 4, 2016, p. 689
18. BECHIR, A., PACURAR, M., PODARIU, A.C., MUCENIC, S., BECHIR, E.S., The Effect of 2-hydroxylethyl Methacrylate on Enamel Abfraction, Rev. Chim. (Bucharest), 65, no. 1, 2014, p.110

19. DROCHIOI, C., COSTAN, V.V., ZAHARIA, M., BOISTEANU, O., SANDU, I.G., EARAR, K., POPESCU, E., FT IR Characterization of Some Biological Materials Used in Reconstructive Surgery. Rev. Chim. (Bucharest), 66, no. 9, 2015, p. 1302

20. TERRY, D.A., MCGUIRE, M.K., MCLAREN, E., FULTON, R., SWIFT, E.J. JR., Perioesthetic approach to the diagnosis and treatment of carious and noncarious cervical lesions: Part II. Journal of Esthetic Restorative Dentistry, 15, 5, 2003, p.284.

21. TERRY, D.A., MCGUIRE, M.K., MCLAREN, E., FULTON, R., SWIFT, E.J JR., Perioesthetic approach to the diagnosis and treatment of carious and noncarious cervical lesions: Part I, J ournal of Esthetic Restorative Dentistry, 15, 4, 2003, p. 217-232.

$\overline{\text { Manuscript received: } 12.09 .2017}$ 